Tropical Journal of Pharmaceutical Research October 2018; 17 (10): 2061-2066

ISSN: $1596-5996$ (print); 1596-9827 (electronic)

(c) Pharmacotherapy Group, Faculty of Pharmacy, University of Benin, Benin City, 300001 Nigeria.

Original Research Article

http://dx.doi.org/10.4314/tjpr.v17i10.24

\title{
Investigation of the presence of pharmaceuticals and personal care products (PPCPs) in groundwater of Jazan area, Saudi Arabia
}

\author{
Abdul Jabbar Al-Rajab ${ }^{1 *}$, Mohammed Al Bratty ${ }^{2}$, Othman Hakami ${ }^{3}$, Hassan A \\ Alhazmi ${ }^{2,4}$, Mukul Sharma ${ }^{1}$, Desam Nagarjuna Reddy ${ }^{1}$ \\ ${ }^{1}$ Centre for Environmental Research and Studies, ${ }^{2}$ Department of Pharmaceutical Chemistry, Faculty of Pharmacy, Jazan \\ University, Jazan, Saudi Arabia, ${ }^{3}$ Department of Chemistry, Faculty of Science, Jazan University, Jazan, Saudi Arabia, \\ ${ }^{4}$ Substance Abuse Research Centre, Jazan University, Jazan, Saudi Arabia
}

*For correspondence: Email: alrajab@hotmail.com; Tel: +1-613-710-1519

Sent for review: 8 May 2018

Revised accepted: 19 September 2018

\begin{abstract}
Purpose: To investigate the possible occurrence of some selected pharmaceutical compounds in the groundwater of Jazan area, Saudi Arabia.

Methods: Water samples from 46 wells were collected from different sites covering Jazan area of Saudi Arabia between February and March 2017. These samples were first analyzed to investigate the presence of eleven drugs mostly used in the study area. Thereafter, samples were subjected to liquid chromatography-mass spectrometry (LC-MS/MS) by direct injection and external standard calibration.

Results: Despite the low detection limit (0.001- $0.02 \mu \mathrm{g} / \mathrm{L})$ applied to the investigated compounds with a variety chemical groups (acetylsalicylic acid, paracetamol, ibuprofen, metronidazole, caffeine, olmesartan, omeprazole, nifedipine, diclofenac sodium, glibenclamide and loratidine), none of these compounds was detected in any of the analyzed samples.

Conclusion: The main source of environmental contamination with pharmaceuticals and personal care products (PPCPS) is wastewater. The results obtained reveal the absence of groundwater contamination by these compounds in Jazan area. However, further extended investigations and monitoring are recommended.
\end{abstract}

Keywords: Pharmaceuticals, Groundwater, Wastewater, Pollution, Personal care products, Liquid chromatography-mass spectrometer (LC-MS/MS)

\footnotetext{
This is an Open Access article that uses a funding model which does not charge readers or their institutions for access and distributed under the terms of the Creative Commons Attribution License (http://creativecommons.org/licenses/by/4.0) and the Budapest Open Access Initiative (http://www.budapestopenaccessinitiative.org/read), which permit unrestricted use, distribution, and reproduction in any medium, provided the original work is properly credited.

Tropical Journal of Pharmaceutical Research is indexed by Science Citation Index (SciSearch), Scopus, International Pharmaceutical Abstract, Chemical Abstracts, Embase, Index Copernicus, EBSCO, African Index Medicus, JournalSeek, Journal Citation Reports/Science Edition, Directory of Open Access Journals (DOAJ), African Journal Online, Bioline International, Open-J-Gate and Pharmacy Abstracts
}

\section{INTRODUCTION}

Pharmaceuticals are the most frequently detected group of pollutants in treated wastewater and groundwater because of their persistence and inefficient removal at wastewater treatment plants [1]. Pharmaceuticals comprise a large and diverse group of compounds including antibiotics, antidepressants, antifungals, bactericides, and other medications designed to prevent, cure and treat disease as well as improve human and animal health [2]. Their worldwide consumption has been on the rise, especially in recent years. Following their use, 
pharmaceuticals are often discharged into the environment, low concentrations have been detected in wastewater and surface water [3]. Pharmaceuticals are some of the most persistent organic pollutants of water and wastewater. Their removal from contaminated water is considered one of the major challenges facing different countries due to the absence of an effective method for their complete elimination. Verlicchi et al [4] showed that many pharmaceuticals are usually detected in raw influent at concentrations of 10.3 to $102 \mu \mathrm{g} / \mathrm{L}$, and that the common wastewater treatment plants (WWTPs) cannot be efficiently employed to remove all the pharmaceutical residues.

WWTPs are the most important sources of pharmaceutical residues in the environment. However, the health and environmental risks of this practice should be investigated [5]. WWTPs utilize biological and physicochemical treatments to remove organic matters and nutrients with no specific attention paid to the removal of emerging pollutants such as pharmaceuticals [4,5]. The environmental behavior and removal of pharmaceuticals has attracted great attention from the scientific community and public since their identification in aqueous samples (drinking, surface and groundwater) [1]. Land application of wastewater and biosolids is a potential route of entry for pharmaceuticals into the environment; their dissipation is likely to be strongly influenced by the environmental conditions (e.g., soil texture, moisture, and temperature) and the biosolids matrix [6,7]. Authors of several studies have investigated the occurrence of pharmaceuticals and personal care products (PPCPs) in surface and groundwater and the efficiency of their removal in WWTPs. Alidina et al [8] reported the occurrence of some PPCPs in the effluent of wastewater treatment plants in Saudi Arabia.

Research on the potential impact of pharmaceuticals on the environment is an important issue that has attracted significant attention in recent years. However, more investigations still need to be made before risks can be fully evaluated. Currently, the pharmaceutical consumption level in Saudi Arabia in among the highest in West Asia; the total pharmaceutical expenditure in Saudi Arabia in 2010 was 13.5 billion SAR (US\$ 3.5 billion) [9].

This study was focused on Jazan area (16.4$\left.18.33^{\circ} \mathrm{N}, 41.4-43.4^{\circ} \mathrm{E}\right)$, located in southwest Saudi Arabia, which covers $13500 \mathrm{~km}^{2}$, with a population of 1.5 million [10]. There is no data available about the environmental impact of PPCPs in Jazan area. Within this context and given the large volume of PPCPs consumed in Saudi Arabia, the potential occurrence of the most frequently used compounds in groundwater of Jazan area was investigated. To the best of our knowledge, this is the first work on the environmental assessment of PPCPs in Jazan area, Saudi Arabia.

\section{EXPERIMENTAL}

\section{Chemicals}

Acetylsalicylic acid, purity $\geq 99 \%$; paracetamol, purity $\geq 98 \%$; ibuprofen, purity $\geq 97 \%$; diclofenac sodium, purity $\geq 98.5 \%$; caffeine, purity $\geq 99 \%$; nifedipine, purity $\geq 98 \%$; omeprazole, purity $\geq 99 \%$; glibenclamide, purity $\geq 99 \%$; metronidazole, purity $\geq 99 \%$; loratadine, purity $\geq 98 \%$, and olmesartan, purity $\geq 98 \%$; as well as formic acid $\geq 95 \%$ and acetonitrile of HPLC grade were purchased from Sigma-Aldrich (Jeddah, Saudi Arabia).

\section{Sample collection}

In total, 46 samples of groundwater were collected from different sites covering Jazan area during February-March 2017 (Fig. 1), whereby the number of samples for each zone was proportional to the population density and human activities. All wells were equipped with electrical pumps. At the sampling time, the pump was operated for about $15 \mathrm{~min}$, and then three $1 \mathrm{~L}$ samples were collected separately using umber glass bottles with an interval of $5 \mathrm{~min}$. Samples were identified, and to prevent potential biodegradation of drugs, $0.1 \mathrm{M} \mathrm{HCl}$ (2 - 3 drops) was added to each water sample to decrease the $\mathrm{pH}$. Samples were transferred in a field cooler to the laboratory of Pharmaceutical Chemistry Department, Faculty of Pharmacy, Jazan University and were analyzed within 10 days.

\section{Analytical method}

Eleven compounds were selected for analysis based on their pattern of use in the study area. The calibration curve and limit of detection for each drug was prepared, and a control standard was injected to ensure the quality of obtained results. Water samples were filtered using 0.45 $\mu \mathrm{m}$ nitrocellulose membranes from SigmaAldrich (Jeddah, Saudi Arabia) before analyzing by LC-MS/MS with direct injection and external standard calibration. The purification and preconcentration process were not required due to the high sensitivity of used analytical technique adopted in this study [11]. Residues of the investigated compounds were determined using a 1200 series high performance liquid 
chromatography HPLC system from Agilent Technologies (Dubai, United Arab Emirates), equipped with an Agilent eclipse plus $\mathrm{C}_{18}$ column (150 mm length $\times 2.1 \mathrm{~mm}$ internal diameter, 3.5 $\mu \mathrm{m}$ particle size). Slow gradient binary mobile phase was used to separate pharmaceuticals of different polarities.

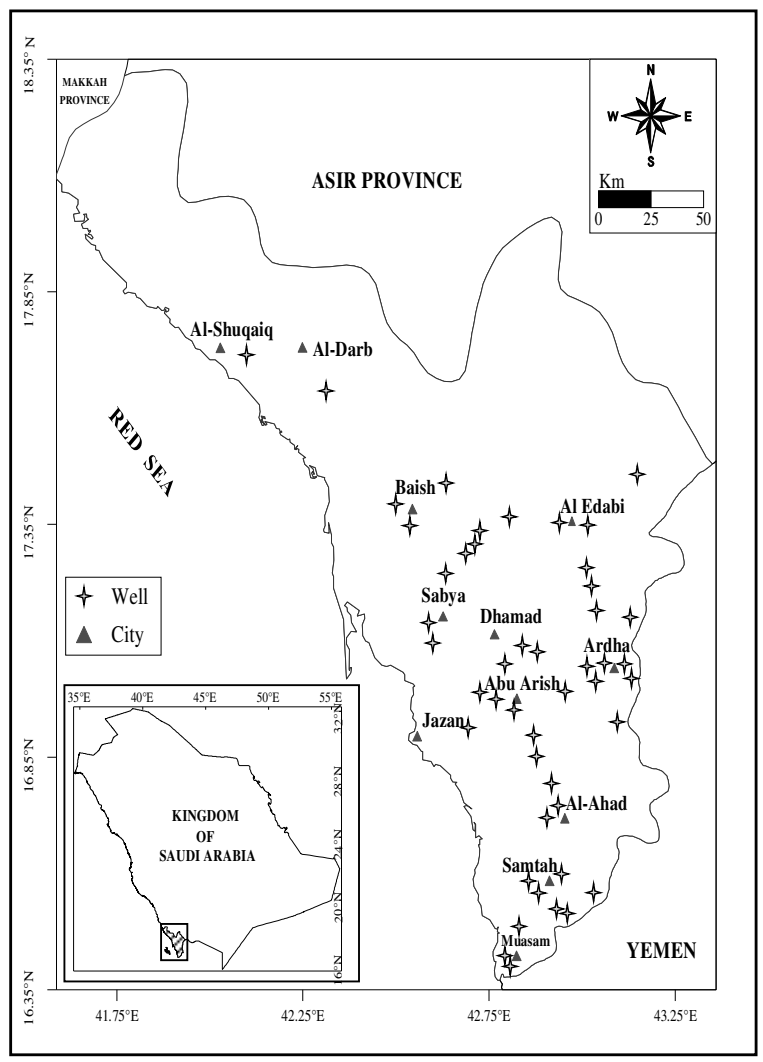

Figure 1: Map of the study location, Jazan, Saudi Arabia

Eluant $A$ was $0.1 \%$ formic acid in $\mathrm{H}_{2} \mathrm{O}$, while eluant $\mathrm{B}$ was acetonitrile. The gradient was started with $5 \%$ of eluant $B$, and was increased to $60 \%$ within $60 \mathrm{~min}$, further increasing to $90 \%$ from 60 to $70 \mathrm{~min}$, after which the percentage of eluant $B$ declined to the initial levels within 5 min at a flow rate of $0.3 \mathrm{ml} \mathrm{min}$. The run time was 75 min, re-equilibration time between samples was $15 \mathrm{~min}$, and the injection volume was $15 \mu \mathrm{L}$ at $22 \pm 1 \stackrel{\circ}{\circ}$.

The HPLC system was coupled to an Agilent 6410 triple-quadruple mass spectrometer (Dubai, United Arab Emirates). The ionization source was operated separately in positive and negative ionization modes with the following conditions: the collision gas was $\mathrm{N}_{2}$ at a flow rate of 12 $\mathrm{L} / \mathrm{min}$, the pressure of $60 \mathrm{psi}, 350 \stackrel{\circ}{ } \mathrm{C}$ desolvation temperature, $4000 \mathrm{~V}$ capillary voltage, and the fragmentor voltage was $145 \mathrm{~V}$. Data acquisition was performed using Mass Hunter software (Agilent). Under the above mentioned conditions, the retention times were: $5.1,19.9,21.2,24.3$, $34.7,42.1,55.5,60.1,60.3$ and $65.3 \mathrm{~min}$ for acetylsalicylic acid, paracetamol, metronidazole, caffeine, olmesartan, omeprazole, nifedipine, diclofenac sodium, glibenclamide and loratidine, respectively.

\section{RESULTS}

The investigated drugs and their key properties are presented in Table 1. None of the water samples from 46 wells representing Jazan area contained detectable residues of the selected drugs. However, there is no previous available data regarding the presence of PPCPs in the groundwater of Saudi Arabia. The investigated compounds were acetylsalicylic acid, paracetamol, ibuprofen, metronidazole, caffeine, olmesartan, omeprazole, nifedipine, diclofenac sodium, glibenclamide, and loratidine.

\section{DISCUSSION}

This is the first investigation focusing on the presence of PPCPs in the groundwater of Saudi Arabia. The only available data about the presence of PPCPs in the local environment of Saudi Arabia was reported by Ali et al [12], where paracetamol, ibuprofen, diclofenac sodium, caffeine and metronidazole were detected in 26 samples of seawater collected from Jeddah's coast on the Red Sea. Our findings are not in accord with those reported by other authors, who noted presence of pharmaceuticals in groundwater in different regions of the world.

In 2011, Lopez et al [15] reported presence of acetaminophen (paracetamol) in $27 \%$ of groundwater samples collected from 494 different sites in France at concentrations below the threshold of toxicological concern $(0.1 \mu \mathrm{g} / \mathrm{L})$.

Gottschall et al [8] detected acetaminophen at a low concentration of $0.013 \mu \mathrm{g} / \mathrm{L}$ in tile water after application of municipal dewatered bio-solids to an agricultural land in Ottawa (Canada), but it was not detected in groundwater at the same experimental site. Moreover, acetaminophen was detected in surface water at low concentrations $(0.001-0.003 \mu \mathrm{g} / \mathrm{L})$ in Yamaska river in Canada in the summer of 2005 [16].

Ibuprofen and diclofenac were not detected in any of the groundwater samples analyzed in this study and this observation is supported by the findings of other authors. Lapworth et al [17] showed that ibuprofen was not detected in any of the 300 chalk ground water samples collected from England and in the 45 samples collected from the French chalk groundwater. 
Table 1: Structure and key properties of investigated drugs $[13,14]$

\begin{tabular}{|c|c|c|c|c|c|}
\hline Compound & Type & Medical use & $\begin{array}{c}\text { Solubility } \\
(\mathrm{mg} / \mathrm{L})\end{array}$ & $\begin{array}{c}\text { MW } \\
(\mathrm{g} / \mathrm{mol})\end{array}$ & Structure \\
\hline $\begin{array}{l}\text { Acetylsalicylic acid } \\
\text { CAS: } 50-78-2 \\
\text { Formula: } \underline{\mathrm{C}}_{9} \underline{\mathrm{H}}_{8} \underline{\mathrm{O}}_{4}\end{array}$ & $\begin{array}{l}\text { Anti- } \\
\text { inflammatory, } \\
\text { antipyretic }\end{array}$ & $\begin{array}{l}\text { Pain, fever, } \\
\text { inflammation }\end{array}$ & 4,600 & 180.16 & \\
\hline $\begin{array}{l}\text { Paracetamol } \\
\text { CAS: } 103-90-2 \\
\text { Formula: } \underline{\mathrm{C}}_{8} \underline{\mathrm{H}}_{9} \underline{\mathrm{NO}_{2}}\end{array}$ & $\begin{array}{l}\text { Anti- } \\
\text { inflammatory }\end{array}$ & $\begin{array}{l}\text { Pain, fever, } \\
\text { cold. }\end{array}$ & 14,000 & 151.16 & \\
\hline $\begin{array}{l}\text { Ibuprofen } \\
\text { CAS: } 15687-27-1 \\
\text { Formula: } \underline{\mathrm{C}}_{13} \underline{\mathrm{H}}_{18} \underline{\mathrm{O}}_{2}\end{array}$ & $\begin{array}{l}\text { Anti- } \\
\text { inflammatory }\end{array}$ & $\begin{array}{l}\text { Pain, fever, } \\
\text { Rheumatism } \\
\text { and arthritis. }\end{array}$ & 21 & 206.28 & \\
\hline $\begin{array}{l}\text { Diclofenac Sodium } \\
\text { CAS: } 15307-79-6 \\
\text { Formula: } \\
\underline{\mathrm{C}}_{14} \underline{\mathrm{H}}_{10} \underline{\mathrm{Cl}_{2}} \underline{\mathrm{NNaO}_{2}}\end{array}$ & $\begin{array}{l}\text { Anti- } \\
\text { inflammatory } \\
\text { agent }\end{array}$ & $\begin{array}{l}\text { Pain, } \\
\text { inflammation } \\
\text { and fever }\end{array}$ & 50 & 318.13 & \\
\hline $\begin{array}{l}\text { Caffeine } \\
\text { CAS: } 58-08-2 \\
\text { Formula: } \mathrm{C}_{8} \mathrm{H}_{10} \mathrm{~N}_{4} \mathrm{O}_{2}\end{array}$ & Stimulant & $\begin{array}{l}\text { Psycho- } \\
\text { pharmaceutic } \\
\text { al }\end{array}$ & 18,700 & 194.19 & \\
\hline $\begin{array}{l}\text { Olmestartan } \\
\text { CAS: } 144689-24-7 \\
\text { Formula: } \\
\underline{\mathrm{C}}_{24} \underline{\mathrm{H}}_{26} \underline{\mathrm{N}}_{6} \underline{\mathrm{O}}_{3} \underline{ }\end{array}$ & $\begin{array}{l}\text { Antihypertensi } \\
\text { ve agent }\end{array}$ & Hypertension & 1.2 & 446.51 & \\
\hline $\begin{array}{l}\text { Nifedipine } \\
\text { CAS:21829-25-4 } \\
\text { Formula: } \mathrm{C}_{17} \mathrm{H}_{18} \mathrm{~N}_{2} \mathrm{O}_{6}\end{array}$ & Anti-anginal & $\begin{array}{l}\text { Calcium } \\
\text { channel } \\
\text { blocker }\end{array}$ & $<1$ & 346.33 & \\
\hline $\begin{array}{l}\text { Omeprazole } \\
\text { CAS: } 73590-58-6 \\
\text { Formula: } \underline{\mathrm{C}}_{17} \underline{\mathrm{H}}_{19} \underline{\mathrm{N}}_{3} \underline{\mathrm{O}}_{3} \underline{\mathrm{S}}\end{array}$ & Antiulcer agent & $\begin{array}{l}\text { Ulcer } \\
\text { therapeutics }\end{array}$ & 35.4 & 345.42 & \\
\hline $\begin{array}{l}\text { Glibenclamide } \\
\text { CAS: } 10238-21-8 \\
\text { Formula: } \underline{\mathrm{C}}_{23} \underline{\mathrm{H}_{28}} \underline{\mathrm{CIN}_{3} \underline{\mathrm{O}}_{5}} \underline{\mathrm{S}}\end{array}$ & $\begin{array}{l}\text { Oral } \\
\text { hypoglycemic } \\
\text { agent }\end{array}$ & Antidiabetic & 4 & 494.00 & \\
\hline $\begin{array}{l}\text { Metronidazole } \\
\text { CAS: } 443-48-1 \\
\text { Formula: } \underline{\mathrm{C}}_{6} \underline{\mathrm{H}_{9}} \underline{\mathrm{N}_{3}} \underline{\mathrm{O}_{3}} \underline{ }\end{array}$ & Antimicrobial & $\begin{array}{l}\text { Amebiasis } \\
\text { and vaginitis } \\
\text { infections }\end{array}$ & 9500 & 171.15 & \\
\hline $\begin{array}{l}\text { Loratadine } \\
\text { CAS: } 79794-75-5 \\
\text { Formula: } \mathrm{C}_{22} \mathrm{H}_{23} \mathrm{CIN}_{2} \mathrm{O}_{2}\end{array}$ & Antihistamine & $\begin{array}{l}\text { Allergic } \\
\text { rhinitis and } \\
\text { urticaria }\end{array}$ & 0.011 & 382.88 & \\
\hline
\end{tabular}

Peng et al [18] reported that the diclofenac was not detected in any of the samples from 27 domestic wells, four groundwater wells, and two reservoirs in the Pearl River Delta, China, during the 2012 - 2013 period. Surprisingly, residues of diclofenac in groundwater of Mexico City at 1 $\mathrm{ng} / \mathrm{L}$ in $7 \%$ of the samples collected during 2009 were reported by Félix-Cañedo et al [19].

Gonzalez-Naranjo et al [20] reported that ibuprofen is moderately adsorbed into four different Spanish agricultural soils with a solidwater distribution coefficient $\mathrm{K}_{d}$ (values ranged from 1.40 to 1.56). This could suggest that the compound might be bioavailable in soil and reach groundwater by leaching. Ibuprofen was detected by Peng et al [18] in $11 \%$ of the groundwater samples collected during 2012 2013 from Guanzgou region (China) at concentrations varying between 19.7 and 57.9 $\mathrm{ng} / \mathrm{L}$. Data about the detection of the loratadine and glibenclamide in groundwater is scarce. 
However, Ternes et al [21] reported that glibenclamide was detected in only 1 out of 11 samples collected from German rivers and streams in 2000 at a concentration of $0.013 \mu \mathrm{g} / \mathrm{L}$. In addition, nifedipine and omeprazole were not detected in any of the analyzed samples.

Trans et al [22] reported presence of caffeine in about $80 \%$ of 148 groundwater samples from an urban catchment area in Singapore at concentrations below the detection limit of 162.5 $\mathrm{ng} / \mathrm{L}$. The concentration of metronidazole was below the detection limit of $0.01 \mu \mathrm{g} / \mathrm{L}$ in all analyzed samples in the current study. These results are in accord with those reported by Lapworth et al [17], who noted that metronidazole was not detected in any of the 300 chalk ground water samples collected from United Kingdom. However, the drug was detected in $4.4 \%$ of 45 samples of French chalk groundwater collected from France in the same study at concentrations that ranged from $<0.01$ to $0.03 \mu \mathrm{g} / \mathrm{L}$.

Balakrishna et al [23], reported presence of metronidazole in the effluent of an Indian hospital (Chandrikaben Rashmikant Gardi) at a low concentration of $3.8 \mu \mathrm{g} / \mathrm{L}$. However, there is no readily available data regarding the occurrence of olmesartan in groundwater. In a review article, Godoy et al [24] reported that 79 studies indicated the presence of 34 different antihypertensive drugs in the aquatic environment. On the other hand, Bayer et al [25] reported that only $17 \%$ of the antihypertensive agent olmesartan was eliminated using a labscale sewage plant. The drug was detected in the effluent of six wastewater treatment plants and in eight Bavaria rivers (Germany) at a median concentration of $1.1 \mu \mathrm{g} / \mathrm{L}$.

Overall, despite the high consumption of pharmaceuticals in Saudi Arabia, no residues were detected for any of the eleven investigated compounds. Our findings indicate that the groundwater in Jazan area is not contaminated with PPCPs. Different factors may account for the absence of the investigated compounds in groundwater, i.e., rapid degradation and removal efficiency. However, further investigations and routine monitoring of PPCPs residues in groundwater are recommended.

\section{DECLARATIONS}

\section{Acknowledgement}

This study was fully funded by Scientific Research Deanship, Jazan University, grant No. JUP 37/7/00043.

\section{Conflict of interest}

No conflict of interest is associated with this work.

\section{Contribution of authors}

We declare that this work was done by the authors named in this article and all liabilities pertaining to claims relating to the content of this article will be borne by the authors. All authors contributed substantially to the work.

\section{REFERENCES}

1. Sui Q, Cao X, Lu S, Zhao W, Qiu Z, Yu G. Occurrence, sources and fate of pharmaceuticals and personal care products in the groundwater: A review. Emer Cont 2015; 1(1): 14-24.

2. Gottschall N, Topp E, Metcalfe C, Edwards M, Payne M, Kleywegt S, Russell P, Lapen DR. Pharmaceuticals and personal care products in groundwater, subsurface drainage, soil, and wheat grain, following a high single application of municipal biosolids to a field. Chemos 2012; 87: 194-203.

3. Al-Rajab AJ, Sabourin L, Scott A, Lapen DR, Topp E. Impact of biosolids on the persistence and dissipation pathways of triclosan and triclocarban in an agricultural soil. Sci Total Environ 2009; 407: 5978-5985.

4. Verlicchi P, Al-Aukidy M, Zambello E. Occurrence of pharmaceutical compounds in urban wastewater: Removal, mass load and environmental risk after a secondary treatment - A review. Sci Total Environ 2012; 429: 123-155.

5. Zhou JL, Zhang ZL, Banks E, Grover D, Jiang JQ. Pharmaceutical residues in wastewater treatment works effluents and their impact on receiving river water. $J$ Hazard Mat 2009; 166: 655-661.

6. Lopez-Serna R, Jurado A, Vazquez-Sune E, Carrera J, Petrovic $M$, Barcelo $D$. Occurrence of 95 pharmaceuticals and transformation products in urban groundwaters underlying the metropolis of Barcelona, Spain. Environ Pollut 2013; 174: 305-315.

7. Al-Rajab AJ, Sabourin L, Lapen D, Topp E. Dissipation of triclosan, triclocarban, carbamazepine and naproxen in agricultural soil following surface or sub-surface application of dewatered municipal biosolids. Sci Total Environ 2015; 512-513: 480-488.

8. Alidina M, Hoppe-Jones C, Yoon M, Hamadeh AF, Li D, Drewes JE. The occurrence of emerging trace organic chemicals in wastewater effluents in Saudi Arabia. Sci Total Environ 2014; 478: 152-162.

9. Bawazir S. Report, Saudi Arabia Pharmaceutical Country Profile. Saudi Food and Drug Authority in collaboration with the World Health Organization 2012; 33p.

10. Al-Hatim HY, Alrajhi D, Al-Rajab AJ. Detection of Pesticide Residue in Dams and Well Water in Jazan 
Area, Saudi Arabia. Amer J Environ Sci 2015; 11(5): 358-365.

11. Luque-Espinar JA, Navas N, Chica-Olmo M, CantareroMalagón S, Chica-Rivas L. Seasonal occurrence and distribution of a group of ECs in the water resources of Granada city metropolitan areas (South of Spain): pollution of raw drinking water. J Hydro 2015; 531(3): 612-625.

12. Ali AM, Ronning HT, Alarif W, Kallenborn R, Al-Lihaibi SS. Occurrence of pharmaceuticals and personal care products in effluent-dominated Saudi Arabian coastal waters of the Red Sea. Chemos 2017; 175: 505-513.

13. Drug Bank database.www.drugbank.ca (Accessed on March 21st, 2018).

14. National Center for Biotechnology Information NCBI. www.ncbi.nlm.nih.gov (Accessed on March 21st, 2018).

15. Lopez B, Ollivier P, Togola A, Baran N, Ghestem JP. Screening of French groundwater for regulated and emerging contaminants. Sci Total Environ 2015; 518: 562-573.

16. Topp E, Monteiro SC, Beck A, Coelho BB, Boxall AB, Duenk PW, Kleywegt S, Lapen DR, Payne M, Sabourin L. Runoff of pharmaceuticals and personal care products following application of biosolids to an agricultural field. Sci Total Environ 2008; 396: 52-59.

17. Yargeau V, Lopata A, Metcalfe C. Pharmaceuticals in the Yamaska River, Quebec, Canada. Water Qual. Res J. Can 2007; 42: 231-239.

18. Lapworth DJ, Baran N, Stuart ME, Manamsa K, Talbot J. Persistent and emerging micro-organic contaminants in Chalk groundwater of England and France. EnvironPol 2015; 203: 214-225.

19. Peng X, Ou W, Wang C, Wang Z, Huang Q, Jin J, Tan J. Occurrence and ecological potential of pharmaceuticals and personal care products in groundwater and reservoirs in the vicinity of municipal landfills in China. Sci Total Environ 2014; 490: 889-898.

20. Félix-Cañedo TE, Durán-Álvarez JC, Jiménez-Cisneros $B$. The occurrence and distribution of a group of organic micropollutants in Mexico City's water sources. Sci Tot Environ 2013; 454-455:109-118.

21. González-Naranjo V, Boltes K, Biel M. Mobility of ibuprofen, a persistent active drug, in soils irrigated with reclaimed water. PI Soil Environ 2013; 59: 68-73.

22. Ternes TA, Bonerz M, Schmidt T. Determination of neutral pharmaceuticals in wastewater and rivers by liquid chromatography-electrospray tandem mass spectrometry. J Chromat A 2001; 938: 175-185.

23. Tran NH, Li J, Hu J, Ong SL. Occurrence and suitability of pharmaceuticals and personal care products as molecular markers for raw wastewater contamination in surface water and groundwater. Environ Sci Pollut Res. Int 2014; 21: 4727-4740.

24. Balakrishna K, Rath A, Praveenkumarreddy $Y$, Guruge $K S$, Subedi B. A review of the occurrence of pharmaceuticals and personal care products in Indian water bodies. Ecotox Environ Saf 2017; 137: 113-120.

25. Godoy AA, Kummrow F, Pamplin PAZ. Occurrence, ecotoxicological effects and risk assessment of antihypertensive pharmaceutical residues in the aquatic environment - A review. Chemos. 2015; 138: 281-291.

26. Bayer A, Asner R, Schüssler W, Kopf W, Weib K, Sengl $M$, Letzel $M$. Behavior of sartans (antihypertensive drugs) in wastewater treatment plants, their occurrence and risk for the aquatic environment. Environ Sci Poll Res 2014; 21: 10830-10839. 